\title{
The role of antioxidant therapy in the treatment of male infertility: an overview
}

\author{
Francesco Lombardo, Andrea Sansone, Francesco Romanelli, Donatella Paoli, Loredana Gandini \\ and Andrea Lenzi
}

In recent years, many studies have focused on the effect of oxidative stress, reactive oxygen species (ROS) and antioxidants on the male eproductive system. Under physiological conditions, sperm produces small amounts of ROS, which are needed for fertilisation, acrosome reaction and capacitation. However, if an increased production of ROS is not associated with a similar increase in scavenging systems, peroxidative damage of the sperm plasma membrane and loss of DNA integrity typically occur, which leads to cell death and reduced fertility. Furthermore, since there is no linear correlation between sperm quality and pregnancy rates, an improvement in semen parameters should not be the sole outcome considered in studies of antioxidant therapies. A definitive conclusion regarding the benefit of these therapies is difficult to obtain, as most of the previous studies lacked control groups, considered different antioxidants in different combinations and doses, or did not evaluate pregnancy rates in previously infertile couples. Even if beneficial effects were reported in a few cases of male infertility, more multicentre, double-blind studies performed with the same criteria are necessary for an increased understanding of the effects of various antioxidants on fertility. Asian Journal of Andrology (2011) 13, 690-697; doi:10.1038/aja.2010.183; published online 20 June 2011

Keywords: antioxidants; male infertility; oxidative stress; reactive oxygen species

\section{INTRODUCTION}

Almost $15 \%$ of all couples trying to conceive are affected by infertility, and in almost half of these cases male infertility is the sole or a contributing factor. ${ }^{1}$ Male infertility can have several causes. The most common is idiopathic oligoasthenoteratozoospermia (OAT), ${ }^{2}$ which is a condition in which sperm concentration, the proportion of morphologically normal sperm and the proportion of motile sperm are all lower than the World Health Organization reference values. ${ }^{3}$ Despite extensive research, a successful treatment for OAT has not yet been developed. Many recent studies have focused on oxidative stress and its possible role in the pathogenesis of male infertility; in physiological conditions, small amounts of reactive oxygen species (ROS) are produced by spermatozoa, and various scavengers act to reduce the concentration of these ROS in the seminal plasma. ROS are needed for capacitation, the acrosome reaction and ultimately fertilisation. ${ }^{4}$ However, excessive production and/or reduced clearance lead to oxidative stress within sperm, resulting in DNA damage, ${ }^{5,6}$ reduced motility $^{7}$ and defective membrane integrity. ${ }^{8,9}$ Antioxidants may help maintain the balance between ROS production and clearance and could thus improve sperm quality. Observational studies have also found a lower frequency of sperm aneuploidy in men with a higher dietary intake of antioxidants than in those with a lower intake. ${ }^{10,11}$

Increased ROS production by leukocytes seems to be a direct consequence of inflammatory processes or of vascular diseases leading to hypoxia or ischaemia, with varicocele playing a significant role. ${ }^{12-15}$ It should also be stressed that immature teratozoospermic forms produce relatively more ROS than normal, mature sperm ${ }^{16}$ and that semen from fertile men has a more effective antioxidant capacity than that from infertile men. ${ }^{11,13}$

Identifying and treating the cause of increased ROS production should be the first step for all infertile male patients; antioxidant supplementation could be useful in increasing the scavenging capacity of seminal plasma, but would not treat the underlying condition that causes the reduced fertility.

The presence of too many variables in most studies that focus on antioxidants and male infertility has also led to controversy, ${ }^{17-19}$ not only because the authors have used different antioxidants, different combinations and different doses in patients with differing characteristics, but also because of the different end points evaluated in their studies. An improvement in sperm quality does not always translate into clinical benefit. Even if a few selected studies have shown that antioxidants have a positive effect on sperm characteristics, there still seems to be no definitive evidence that this therapy leads to higher pregnancy rates. $^{20-27}$

\section{LITERATURE SEARCH}

The MEDLINE database was searched using PubMed with various keywords, including various combinations of search terms. 'Male infertility', 'antioxidants', 'ROS' and 'oxidative stress' were the most relevant search terms, combined via Boolean operators. From the numerous search results, 54 primary studies were chosen and their data were gathered in order to provide a complete overview of the 
literature. Given the different antioxidants used (both alone and in combination), the different dosages, the in vivo or in vitro methodology and the different study end points, the following discussion should be considered alongside the data reported in Table $\mathbf{1}$.

All studies were chosen on the basis of their quality; studies that were biased, incomplete or otherwise considered untrustworthy were excluded.

\section{RESULTS}

\section{Vitamin E}

Vitamin E, a major chain breaking antioxidant in membranes, has been evaluated in numerous studies (Table 1). Only four of these studies ${ }^{28-31}$ found little or no effect on semen parameters, whereas beneficial effects were reported in the remaining 18 studies. $^{8,19,32-47}$

In vitro studies. Two studies by Aitken et al. ${ }^{8,32}$ on the effects of vitamin $\mathrm{E}$ showed that $10 \mathrm{mmol}^{-1}$ suppressed lipid peroxidation, leading to preserved motility in vitro, with a dose-dependent effect. Askari et al. ${ }^{33}$ reported the effect of vitamin $\mathrm{E}\left(10 \mathrm{mmol}^{-1}\right)$ in combination with cryoprotectants in preserving sperm motility during thawing procedures. In fact, oxidative stress from cryopreservation is commonly associated with a dramatic decrease in sperm motility, ${ }^{48,49}$ and vitamin $\mathrm{E}$ seems to be capable of preserving sperm motility more than cryoprotectants alone.

Hughes et al. ${ }^{38}$ noted the importance of vitamins C (300$\left.600 \mu \mathrm{mol} 1^{-1}\right)$ and $\mathrm{E}\left(30-60 \mu \mathrm{mol} \mathrm{l^{-1 }}\right)$ in preserving sperm DNA integrity in Percoll preparations; however, this combination has produced contrasting results with exacerbated DNA damage, which is likely due to pro-oxidant effects.

Twigg et al. ${ }^{19}$ found that an in vitro dose of $1 \mathrm{mmol}^{-1}$ of vitamin $\mathrm{E}$ had no effect on lipid peroxidation induced by nicotinamide adenine dinucleotide phosphate. Thus, it is possible that the effectiveness of vitamin $\mathrm{E}$ and other antioxidants on lipid peroxidation depends on the source of oxidative stress.

In 1999, Donnelly et al. ${ }^{39,40}$ observed reduced $\mathrm{H}_{2} \mathrm{O}_{2}$-induced ROS production and DNA damage after the addition of both vitamin $\mathrm{C}$ (300 and $600 \mu \mathrm{mol} \mathrm{l}^{-1}$ ) and vitamin E (40 and $60 \mu \mathrm{mol} \mathrm{l}{ }^{-1}$ ) to normozoospermic and asthenozoospermic samples. In 2002, Sierens et al. ${ }^{42}$ observed similar results after the addition of $1-100 \mu \mathrm{mol} 1^{-1}$ of vitamin $\mathrm{E}$ and $100-200 \mu \mathrm{mol} \mathrm{l}^{-1}$ of vitamin C, both able to reduce DNA damage induced by $\mathrm{H}_{2} \mathrm{O}_{2}$ in vitro.

In vivo studies. In 1996, Suleiman et al. ${ }^{36}$ conducted a randomized, double-blind, controlled trial on 110 asthenozoospermic subjects in which the administration of $300 \mathrm{mg}$ day ${ }^{-1}$ of vitamin $\mathrm{E}$ for 6 months led to reduced lipid peroxidation, a significant increase in motility and, most importantly, a significantly improved pregnancy rate, with no increase in the control group.

Also in 1996, Vezina et al. ${ }^{35}$ administered a combination of vitamin $\mathrm{E}$ and selenium $\left(400 \mathrm{mg}\right.$ day $^{-1}$ plus $100 \mathrm{\mu g} \mathrm{day}^{-1}$ for 1 month and $400 \mathrm{mg} \mathrm{day}^{-1}$ plus $200 \mathrm{\mu g} \mathrm{day}^{-1}$ for the next 5 months) to nine patients with oligoasthenozoospermia, which produced a significant improvement in sperm motility, viability and morphology. Keskes-Ammar et al.' ${ }^{43}$ more recent study of $400 \mathrm{mg}$ day $^{-1}$ of vitamin $\mathrm{E}$ and $225 \mu \mathrm{g}$ day $^{-1}$ of selenium in 53 patients found the motility of sperm from volunteers and infertile patients to be increased after 3 months, supporting the positive effects of this treatment.

Kodama et $a l^{37}$ observed increased sperm concentration and reduced DNA damage in 36 infertile patients who underwent 2 months of therapy with vitamin E (200 $\left.\mathrm{mg}^{\text {day }}{ }^{-1}\right)$, vitamin C $\left(200 \mathrm{mg} \mathrm{day}^{-1}\right)$ and glutathione (GSH; $400 \mathrm{mg} \mathrm{day}^{-1}$ ), with no improvement in motility or morphology.

Comhaire et $a l^{41}$ studied the effects of a combination therapy of $180 \mathrm{mg}$ day $^{-1}$ vitamin $\mathrm{E}$ and $30 \mathrm{mg}$ day $^{-1} \beta$-carotene on a group of 27 infertile men: ROS production was significantly reduced, although no significant improvements were observed in semen parameters.

Greco et al. ${ }^{44}$ reported a significant improvement in 38 men with elevated sperm DNA fragmentation after 2 months of combined therapy with $1 \mathrm{~g}$ of vitamin $\mathrm{C}$ and $1 \mathrm{~g}$ of vitamin $\mathrm{E}$ daily: compared with an initial failed intracytoplasmic sperm injection attempt before treatment, clinical pregnancy and implantation rates showed a marked increase after the second attempt.

In 2008, Paradiso Galatioto et al. ${ }^{47}$ used a multi-drug therapy including several antioxidants (consisting of daily administration of vitamin A $0.06 \mathrm{IU} \mathrm{kg}^{-1}$, vitamin C $3 \mathrm{mg} \mathrm{kg}^{-1}$, vitamin E $0.2 \mathrm{mg}$ $\mathrm{kg}^{-1}, \mathrm{~N}$-acetyl-cysteine (NAC) $10 \mathrm{mg} \mathrm{kg}{ }^{-1}$, zinc $0.01 \mathrm{mg} \mathrm{kg}^{-1}$, thiamine $0.4 \mathrm{mg} \mathrm{kg}^{-1}$, riboXavin $0.1 \mathrm{mg} \mathrm{kg}^{-1}$, piridoxin $0.2 \mathrm{mg}$ $\mathrm{kg}^{-1}$, nicotinamide $1 \mathrm{mg} \mathrm{kg}^{-1}$, pantothenate $0.2 \mathrm{mg} \mathrm{kg}^{-1}$, biotin $0.04 \mathrm{mg} \mathrm{kg}{ }^{-1}$, cyanocobalamin $0.1 \mathrm{mg} \mathrm{kg}^{-1}$, ergocalciferol $8 \mathrm{IU}$ $\mathrm{kg}^{-1}$, calcium $1 \mathrm{mg} \mathrm{kg}^{-1}$, magnesium $0.35 \mathrm{mg} \mathrm{kg}^{-1}$, phosphate $0.45 \mathrm{mg} \mathrm{kg}^{-1}$, iron $0.2 \mathrm{mg} \mathrm{kg}^{-1}$, manganese $0.01 \mathrm{mg} \mathrm{kg}^{-1} \mathrm{day}^{-1}$, copper $0.02 \mathrm{mg} \mathrm{kg}^{-1} \mathrm{day}^{-1}$ ) in 42 oligozoospermic subjects: the treatment group had a 20 -fold higher chance of having a normal sperm count than untreated men, and a nonsignificant increase in the chance of achieving pregnancy.

Also in 2008, Omu et al. ${ }^{45}$ performed a trial on 45 asthenozoospermic men who received various combinations of vitamin $\mathrm{E}$, vitamin $\mathrm{C}$ and zinc for 3 months, producing a reduction in oxidative stress, sperm apoptosis and sperm DNA fragmentation index. No significant differences were seen between zinc monotherapy and its combination with either or both vitamins.

As previously noted, only four studies found in vivo vitamin $\mathrm{E}$ supplementation to have no effect on semen parameters. In 1995, Kessopoulou et al. $^{28}$ and Moilanen and Hovatta ${ }^{29}$ administered vitamin E $600 \mathrm{mg} \mathrm{day}^{-1}$ for 3 months and 600,800 or $1200 \mathrm{mg}$ $\mathrm{day}^{-1}$ for 3 weeks, respectively, finding increased concentrations of vitamin $\mathrm{E}$ in plasma and semen but no changes in semen parameters. In 1996, Geva et al. ${ }^{30}$ conducted a prospective study on 15 antiretroviral therapy patients, in which the administration of $200 \mathrm{mg} \mathrm{day}^{-1}$ for 3 months produced no changes in sperm morphology. Similarly, Rolf et al. ${ }^{31}$ found no positive effects after the administration of a combination of vitamins C and E (1000 and $800 \mathrm{mg}$ daily) for 56 days, with no increase in motility, viability, concentration and morphology in any of the 33 asthenozoospermic patients who participated in the study.

\section{Vitamin C}

Vitamin $C$ is another chain breaking antioxidant whose effects on sperm have been extensively studied since 1982 .

In vitro studies. Hughes et al. ${ }^{38}$ found that 300 and $600 \mu \mathrm{mol} 1^{-1}$ of vitamin $\mathrm{C}$ protected against $\mathrm{H}_{2} \mathrm{O}_{2}$-induced DNA damage during Percoll preparations, as did 30-60 $\mu \mathrm{mol}^{-1}$ of vitamin E (as discussed above), with a paradoxical toxicity resulting from the combination of the two vitamins.

Also in 1998, Verma and Kanwar $^{34}$ confirmed the paradoxical ability of vitamin $\mathrm{C}$ to increase ROS production, with doses greater than $1000 \mu \mathrm{mol} 1^{-1}$ resulting in motility loss in vitro, probably due to reactions with catalytic ions. However, at lower doses, a dose-dependent 
Table 1 An overview of the different antioxidants used (both alone and in combination), the different dosages, the in vivo or in vitro methodology and the different study end points.

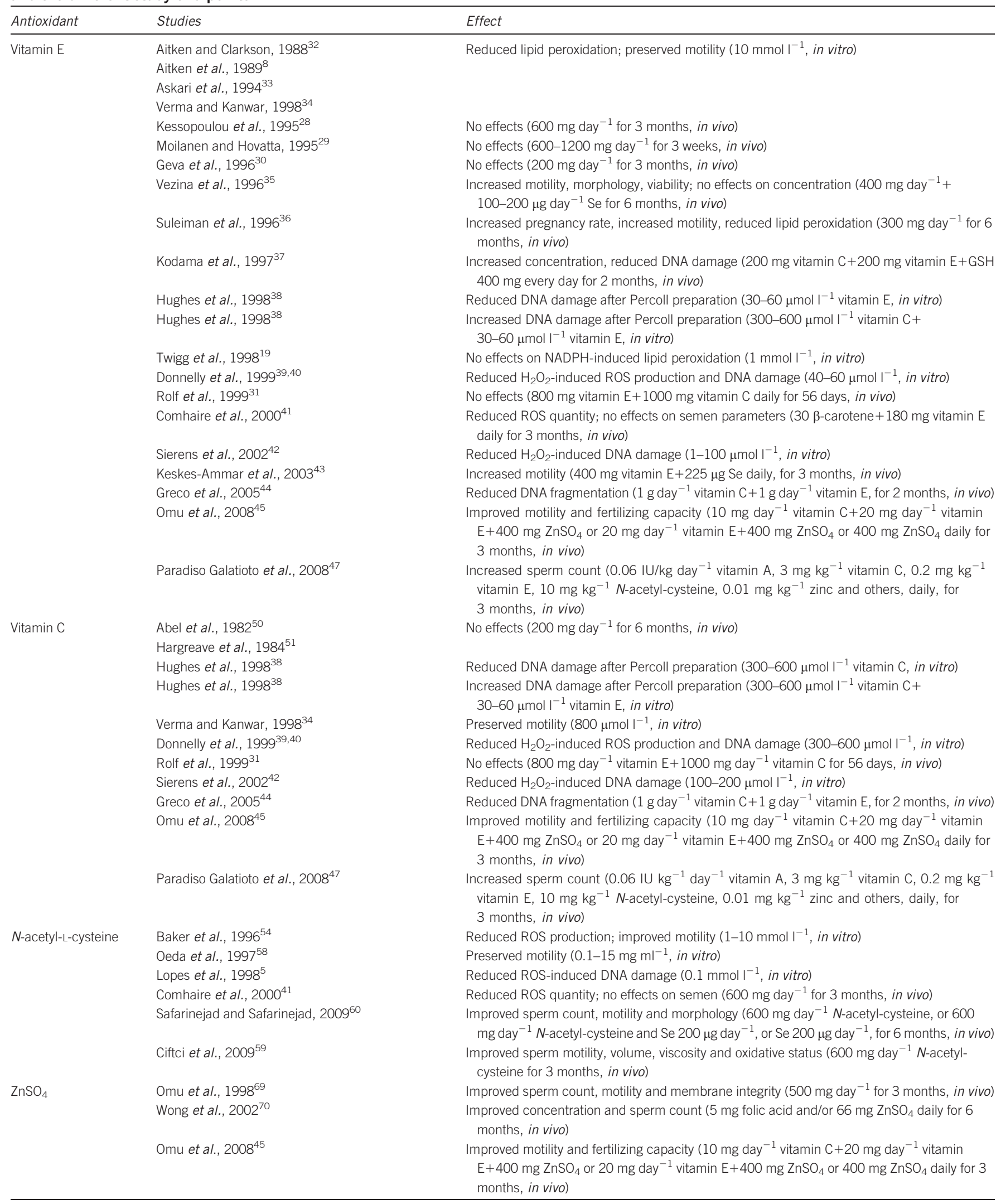


Table 1 (Continued) An overview of the different antioxidants used (both alone and in combination), the different dosages, the in vivo or in vitro methodology and the different study end points.

\begin{tabular}{|c|c|c|}
\hline Antioxidant & Studies & Effect \\
\hline \multirow[t]{7}{*}{ GSH } & Lenzi et al., $1993^{56}$ & $\begin{array}{l}\text { Improved motility and morphology; no effects on concentration ( } 600 \text { mg alternative day }^{-1} \text { for } 2 \\
\text { months, in vivo) }\end{array}$ \\
\hline & Lenzi et al., $1994^{57}$ & $\begin{array}{l}\text { Improved motility, morphology and concentration ( } 600 \mathrm{mg} \text { alternative day }{ }^{-1} \text { for } 2 \text { months, } \\
\text { in vivo) }\end{array}$ \\
\hline & Griveau and Le Lannou, $1994^{52}$ & Reduced ROS-induced DNA damage (10 mmol $\mathrm{I}^{-1}$, in vitro) \\
\hline & Lopes et al., $1998^{5}$ & \\
\hline & Hong et al., $1994^{53}$ & Preserved tail-beat frequency (5-10 mmol $\mathrm{I}^{-1}$, in vitro) \\
\hline & Baker et al., $1996^{54}$ & Preserved motility ( $1-10 \mathrm{mmol} \mathrm{I}^{-1}$, in vitro) \\
\hline & Parinaud et al., $1997^{55}$ & Preserved motility (in vitro, in leukocytospermic samples) \\
\hline \multirow[t]{5}{*}{ Pentoxifylline } & Gavella et al., $1991^{71}$ & Reduced production ( $10 \mathrm{mmol} \mathrm{I}^{-1}$, in vitro) \\
\hline & Gavella and Lipovac, $1992^{72}$ & \\
\hline & McKinney et al., $1996^{73}$ & Reduced ROS production; reduced lipid peroxidation (3.6-7.2 mmol $\mathrm{I}^{-1}$, in vitro) \\
\hline & Okada et al., $1997^{74}$ & $\begin{array}{l}\text { Prevented loss of curvilinear velocity and beat-cross frequency; reduced ROS production; } \\
\text { reduced lipid peroxidation ( } 1-10 \mathrm{mmol} \mathrm{I}^{-1} \text {, in vitro) }\end{array}$ \\
\hline & Twigg et al., $1998^{19}$ & No effects on lipid peroxidation $\left(3.6 \mathrm{mmol}^{-1}\right.$, in vitro) \\
\hline \multirow[t]{8}{*}{ Carnitine } & Costa et al., $1994^{61}$ & Improved motility, morphology and concentration ( $3 \mathrm{~g}$ day $^{-1}$ L-carnitine for $^{2}$ months, in vivo) \\
\hline & Vicari and Calogero, $2001^{62}$ & $\begin{array}{l}\text { Increased motility and viability, reduced ROS quantity; no effects on concentration or } \\
\left.\text { morphology ( } 2 \mathrm{~g} \text { day }^{-1} \text { carnitine, } 1 \mathrm{~g} \text { day }{ }^{-1} \text { acetylcarnitine, for } 3 \text { months, in vivo }\right)\end{array}$ \\
\hline & Vicari et al., $2002^{63}$ & $\begin{array}{l}\text { Increased motility and viability, reduced ROS quantity; no effects on concentration or } \\
\text { morphology ( } 2 \mathrm{~g} \mathrm{day}^{-1} \text { carnitine, } 1 \mathrm{~g}^{-1} \text { day }^{-1} \text { acetylcarnitine, for } 4 \text { months, in vivo) }\end{array}$ \\
\hline & Lenzi et al., $2003^{64}$ & Increased concentration and motility ( $2 \mathrm{~g}$ day ${ }^{-1}$ carnitine for 6 months, in vivo) \\
\hline & Lenzi et al., $2004^{65}$ & $\begin{array}{l}\text { Increased sperm count and motility (carnitine } 2 \mathrm{~g} \text { day } \\
\text { months, in vivo) }\end{array}$ \\
\hline & Cavallini et al., $2004^{66}$ & $\begin{array}{l}\text { Improved concentration, motility and morphology (carnitine } 2 \mathrm{~g}+\text { acetyl-L-carnitine } 1 \mathrm{~g} \text { daily for } \\
4 \text { months, in vivo) }\end{array}$ \\
\hline & Balercia et al., $2005^{67}$ & $\begin{array}{l}\text { Increased velocity ( } L \text {-carnitine } 3 \mathrm{~g}_{\text {day }}{ }^{-1} \text {, or acetyl-L-carnitine } 3 \mathrm{~g}_{\text {day }}{ }^{-1} \text {, or } L \text {-carnitine } \\
22 \text { g day }^{-1}+\text { acetyl-L-carnitine } 1 \mathrm{~g} \mathrm{day}^{-1} \text {, for } 6 \text { months, in vivo) }\end{array}$ \\
\hline & Sigman et al., $2006^{68}$ & No effects ( $L$-carnitine $2 \mathrm{~g}$ day $^{-1}+L$-acetyl-carnitine $1 \mathrm{~g}$ day $^{-1}$ for 6 months, in vivo) \\
\hline \multirow[t]{4}{*}{ Catalase } & Kovalski et al., $1992^{79}$ & Preserved motility; reduced lipid peroxidation; reduced DNA damage $\left(0.008-0.1 \mathrm{mg} \mathrm{ml}^{-1}\right.$; \\
\hline & Griveau and Le Lannou, $1994^{52}$ & 50-2000 IU ml ${ }^{-1}$, in vitro) \\
\hline & Lopes et al., $1998^{5}$ & \\
\hline & Twigg et al., $1998^{19}$ & No effects on lipid peroxidation $\left(250,500\right.$ or $2000 \mathrm{IU} \mathrm{ml}^{-1}$, in vitro) \\
\hline \multirow[t]{5}{*}{ Selenium } & Iwanier and Zachara, $1995^{75}$ & No effects $\left(200 \mu\right.$ day $^{-1}$ for 3 months, in vivo) \\
\hline & Vezina et al., $1996^{35}$ & $\begin{array}{l}\text { Increased motility, morphology, viability; no effects on concentration [100 } \mu \mathrm{g}^{\text {day }}{ }^{-1} \\
\text { (1 month) }+200 \mu \text { day }^{-1} \text { (5 months) }+400 \text { mg vitamin } E \text { for } 6 \text { months, in vivo] }\end{array}$ \\
\hline & Scott et al., $1998^{76}$ & $\begin{array}{l}\text { Improved motility; no increase in concentration ( } 100 \mu \text { day }^{-1} \mathrm{Se} \text {, or Se+1 mg vitamin A, } 10 \mathrm{mg} \\
\text { vitamin C, } 15 \text { mg vitamin E daily, for } 3 \text { months, in vivo) }\end{array}$ \\
\hline & Keskes-Ammar et al., $2003^{43}$ & Increased motility (400 mg vitamin $\mathrm{E}+225 \mu \mathrm{g}$ Se daily, for 3 months, in vivo) \\
\hline & Safarinejad and Safarinejad, $2009^{60}$ & $\begin{array}{l}\text { Improved sperm count, motility and morphology (600 mg day }{ }^{-1} N \text {-acetyl-cysteine, or } 600 \mathrm{mg} \\
\text { day }^{-1} \mathrm{~N} \text {-acetyl-cysteine and Se } 200 \mu \text { day }^{-1} \text {, or Se } 200 \mu \text { day }^{-1} \text { daily, for } 6 \text { months) }\end{array}$ \\
\hline \multirow[t]{6}{*}{ SOD } & Kobayashi et al., $1991^{77}$ & Preserved motility; reduced lipid peroxidation (87.5-500 $\mathrm{IU} \mathrm{ml}^{-1}$, in vitro) \\
\hline & Aitken et al., $1993^{78}$ & \\
\hline & Griveau and Le Lannou, $1994^{52}$ & \\
\hline & Lopes et al., $1998^{5}$ & \\
\hline & Kovalski et al., $1992^{79}$ & Preserved motility $\left(1 \mathrm{mg} \mathrm{ml}^{-1}\right.$, in vitro) \\
\hline & Twigg et al., $1998^{19}$ & No effects on lipid peroxidation $\left(100,250\right.$ or $500 \mathrm{IU} \mathrm{ml}^{-1}$, in vitro) \\
\hline \multirow[t]{2}{*}{ Coenzyme Q10 } & Lewin and Lavon, $1997^{80}$ & $\begin{array}{l}\text { Improved motility ( } 50 \mu \mathrm{mol} \mathrm{I} \\
\text { morphology or concentration ( } 60 \mathrm{mg}^{-1} \text { day }^{-1} \text { for } 103 \text { days, in vivo) }\end{array}$ \\
\hline & Balercia et al., $2009^{81}$ & Improved motility (200 $\mathrm{mg}$ day ${ }^{-1}$ for 6 months, in vivo) \\
\hline Other compounds & Paradiso Galatioto et al., $2008^{47}$ & $\begin{array}{l}\text { Increased sperm count (0.06 IU kg }{ }^{-1} \text { day }^{-1} \text { vitamin } \mathrm{A}, 3 \mathrm{mg} \mathrm{kg}^{-1} \text { vitamin } \mathrm{C}, 0.2 \mathrm{mg} \mathrm{kg}^{-1} \\
\text { vitamin } \mathrm{E}, 10 \mathrm{mg} \mathrm{kg}^{-1} \mathrm{~N} \text {-acetyl-cysteine, } 0.01 \mathrm{mg} \mathrm{kg}^{-1} \text { zinc and others, daily, } \\
\text { for } 3 \text { months, in vivo) }\end{array}$ \\
\hline
\end{tabular}

Abbreviations: GSH, glutathione; NADPH, nicotinamide adenine dinucleotide phosphate, ROS, reactive oxygen species; SOD, superoxide dismutase.

effect was observed, with maximum motility achieved after incubation in $800 \mu \mathrm{mol} \mathrm{l}^{-1}$ for $6 \mathrm{~h}$.

As noted above, the trials conducted by Donnelly et al..$^{39,40}$ in 1999, which used both vitamin C (300 and $\left.600 \mu \mathrm{mol} \mathrm{l}^{-1}\right)$ and vitamin E (40 and $\left.60 \mu \mathrm{mol} 1^{-1}\right)$, and by Sierens et al. ${ }^{42}$ in 2002 which used 1$100 \mu \mathrm{mol}^{-1}$ of vitamin E and $100-200 \mu \mathrm{mol}^{-1}$ of vitamin C, found reduced $\mathrm{H}_{2} \mathrm{O}_{2}$-induced ROS production and DNA damage in both normozoospermic and asthenozoospermic samples.
In vivo studies. Abel et al..$^{50}$ and Hargreave et al. ${ }^{51}$ found no effects of the administration of $200 \mathrm{mg}^{\text {day }}{ }^{-1}$ of vitamin C for 6 months and a lower pregnancy rate compared with other treatments (respectively clomiphene citrate and mesterolone), although no comparison was made between vitamin $\mathrm{C}$ and placebo.

As reported above, Rolf et al. ${ }^{31}$ found no effects on motility, viability, concentration or morphology in 33 asthenozoospermic patients after 56 days of therapy with $1000 \mathrm{mg}$ of vitamin $\mathrm{C}$ and $800 \mathrm{mg}$ of vitamin $\mathrm{E}$. 
The results of other studies in which vitamins $\mathrm{C}$ and $\mathrm{E}$ were administered in combination have already been discussed. ${ }^{44-47}$

\section{GSH}

Because of its widely known antioxidant properties, GSH has been investigated as a possible therapy for infertile patients.

In vitro studies. Studies conducted by Griveau and Le Lannou ${ }^{52}$ and by Lopes et al. ${ }^{5}$ have shown protective effects of $10 \mathrm{mmol} \mathrm{l}^{-1}$ of GSH against DNA damage induced by ROS., ${ }^{5,52}$ Hong et al. ${ }^{53}$ and Baker et al. ${ }^{54}$ observed preserved tail-beat frequency and the protective effect of $5-10$ and $1-10 \mathrm{mmol} 1^{-1}$ GSH in vitro against the impairment of sperm motility by activated polymorphonuclear leukocytes. $^{53,54}$

Parinaud and colleagues ${ }^{55}$ studied the effects of Sperm-Fit, an antioxidant solution containing glucose and GSH, on sperm motility. They found that motility was preserved in leukocytospermic samples, thus improving the chance of recovering motile sperm after liquefaction and centrifugation.

In vivo studies. Two trials performed by our group showed that GSH had a positive, statistically significant effect on sperm parameters. The first, conducted in 1993, found that $600 \mathrm{mg}$ of GSH administered every other day for 2 months led to improved motility and morphology in 21 men treated with varicocele or male accessory gland infection. The second, conducted the following year on 10 infertile men with the same characteristics, led to similar results, although a significant increase in sperm concentration was also found. ${ }^{56,57}$

\section{NAC}

NAC is a precursor of GSH and has thus been used as an antioxidant in several studies and trials.

In vitro studies. The most noteworthy studies are those performed by Baker et al. ${ }^{54}$ Oeda et al. ${ }^{58}$ and Lopes et al. ${ }^{5}$ which showed positive effects with varying doses in vitro. Baker et al. ${ }^{54}$ observed reduced ROS production and improved motility with doses ranging from 1 to $10 \mathrm{mmol}^{-1}$, whereas Oeda et al ${ }^{58}$ observed preserved motility with doses from 0.1 to $15 \mathrm{mg} \mathrm{ml}^{-1}$ and Lopes et al. ${ }^{5}$ found reduced DNA damage with $0.1 \mathrm{mmol}^{-1}$ of NAC.

In vivo studies. The three most relevant in vivo studies gave conflicting results: Comhaire et al. ${ }^{41}$ found no improvements in sperm parameters after 3 months' administration of NAC $600 \mathrm{mg}^{\text {day }}{ }^{-1}$; whereas the same dosage seemed to improve sperm motility, volume, viscosity and oxidative status in Ciftci et al. trial ${ }^{59}$ in 2009 with 120 infertile men. Finally, in a trial of 468 patients with idiopathic OAT treated for 6 months with $600 \mathrm{mg}$ day $^{-1}$ of NAC or $200 \mu \mathrm{g} \mathrm{day}^{-1}$ of selenium or both, an improvement in sperm count, motility and morphology was seen, with additive beneficial effects when both therapies were administered. $^{60}$

\section{Carnitine}

The antioxidant action of carnitines protects against lipid peroxidation of lipid membranes, inspiring a large number of in vivo trials evaluating their effect on sperm parameters.

In the trial by Costa and colleagues ${ }^{61}, 3 \mathrm{~g} \mathrm{day}^{-1}$ of $L$-carnitine was administered to 100 asthenozoospermic men. After 4 months of treatment, a significant improvement was observed in sperm concentration, motility and morphology.

Vicari and Cologero ${ }^{62}$ and later Vicari et al. ${ }^{63}$ evaluated the effects of $2 \mathrm{~g} \mathrm{day}^{-1}$ of carnitine in combination with $1 \mathrm{~g} \mathrm{day}^{-1}$ of acetylcarnitine: the first study ${ }^{62}$ was performed on 54 men suffering from prostate-vesiculo-epididymitis, while the second ${ }^{63}$ involved 98 men with the same condition. In both studies, a significant improvement was reported in sperm motility, viability, leukocytes and ROS production; however, no differences were seen in concentration or morphology.

Lenzi et al., ${ }^{64}$ in 2003, found that $2 \mathrm{~g} \mathrm{day}^{-1}$ of carnitine for 6 months produced a significant improvement in sperm concentration and motility in 100 patients with OAT, while the following year an increased sperm count and improved motility were found in 56 infertile men after combined daily treatment with carnitine and acetyl-L-carnitine (2 and $1 \mathrm{~g}$, respectively) for 6 months. ${ }^{65}$

A study of 219 men with varicocele also reported an increase in sperm concentration and motility and improved morphology after 4 months with the same treatment, although the improvements were less marked in subjects with grade IV or $\mathrm{V}$ varicocele. ${ }^{66}$ Balercia et al. ${ }^{67}$ tested different doses of $L$-carnitine and acetyl- $L$ carnitine (3 $\mathrm{g}$ of $L$-carnitine, $3 \mathrm{~g}$ of acetyl- $L$-carnitine, or $2 \mathrm{~g} L$ carnitine and $1 \mathrm{~g}$ acetyl- $L$-carnitine daily), reporting increased velocity in 60 asthenozoospermic subjects. In contrast, in 2006 Sigman et $a l .{ }^{68}$ found no improvements in semen parameters in 26 men diagnosed with asthenozoospermia who underwent 6 months of treatment with $L$-carnitine and $L$-acetyl-carnitine with 2 and $1 \mathrm{~g}$ day $^{-1}$, respectively.

\section{Zinc}

Zinc sulphate has been proposed as an infertility treatment, although only a few studies have reported its effects on semen parameters when administered in vivo.

Omu et al. ${ }^{4569}$ have published two studies in which $\mathrm{ZnSO}_{4}$ was used: in the first, $500 \mathrm{mg}$ day ${ }^{-1}$ of $\mathrm{ZnSO}_{4}$ was administered to 100 asthenozoospermic men for 3 months, and a significant improvement was observed in sperm count, motility and membrane integrity. ${ }^{69}$ The second study, published 10 years later, used a combination of drugs and is discussed above. ${ }^{45}$

Wong et al. ${ }^{70}$ observed an increased sperm count and improved semen concentration in a controlled trial with 103 infertile and 107 fertile men who had taken $5 \mathrm{mg}$ folic acid and $66 \mathrm{mg} \mathrm{ZnSO}_{4}$ per day for 6 months, either alone or in combination; however, it should be noted that the fertile men did not achieve significant improvements in any of the parameters, most notably concentration.

\section{Pentoxyfilline}

In vitro studies have demonstrated that pentoxifylline has a beneficial effect on sperm parameters. Gavella et al. ${ }^{71}$ and Gavella and Lipovac ${ }^{72}$ found that superoxide anion production was reduced by the addition of $10 \mathrm{mmol}^{-1}$ of pentoxifylline, as did McKinney et $a .^{73}$ and Okada et al. ${ }^{74}$ in their respective studies, albeit with different doses. It should also be stressed that in McKinney's study ${ }^{73}$ reduced lipid peroxidation was observed after the addition of pentoxifylline (dosages from 3.6 to $7.2 \mathrm{mmol}^{-1}$ ), and that in Okada's study ${ }^{74}$ doses from 1 to $10 \mathrm{mmol} \mathrm{l}^{-1}$ led to preserved motility, due to reduced loss of curvilinear velocity and beat-cross frequency. $^{71-74}$

However, in 1998 Twigg et al. ${ }^{19}$ found no improvement in lipid peroxidation after the addition of $3.6 \mathrm{mmol}^{-1}$ of pentoxifylline. 


\section{Selenium}

Finding concrete evidence of the benefits of in vivo selenium therapy is problematic, as different studies with different dosages have led to conflicting results.

Iwanier and Zachara ${ }^{75}$ found no positive effects after 3 months of treatment with selenium at a dose of $200 \mu \mathrm{g} \mathrm{day}^{-1}$ in 33 subfertile men. ${ }^{75}$ However, most other studies have reported improvements in numerous parameters after several months of combined therapy with selenium and other antioxidants. Vezina et al. ${ }^{35}$ combined selenium and vitamin E, leading to improvements in sperm motility, morphology and viability; however, concentration did not change significantly, as already discussed. In 1998, Scott et al. ${ }^{76}$ conducted a trial with 64 men (of whom 46 had previously been diagnosed with OAT and 16 were classified as subfertile), administering selenium alone or in combination with vitamins $\mathrm{A}, \mathrm{C}$ and $\mathrm{E}$ at daily doses of $100 \mu \mathrm{g}, 1 \mathrm{mg}$, $10 \mathrm{mg}$ and $15 \mathrm{mg}$ respectively. No improvement was observed in sperm concentration after 3 months, although motility was increased in treated subjects.

As already described, the trials conducted by Keskes-Ammar et al. ${ }^{43}$ in 2003 and by Safarinejad and Safarinejad ${ }^{60}$ in 2009 used a combination therapy - selenium and vitamin $\mathrm{E}$ in the former and selenium and NAC in the latter-which led to increased motility in both studies and to an improvement in sperm count and morphology in the latter.

\section{Superoxide dismutase (SOD)}

There is some consensus on the beneficial effects of SOD on lipid peroxidation in vitro: several studies, published between 1991 and $1998,5,52,77,78$ reported improved motility and reduced lipid peroxidation in samples dosed with between 87.7 and $500 \mathrm{IU} \mathrm{ml}^{-1}$ of SOD. Similarly, in 1992 Kovalski et al. ${ }^{79}$ found that the addition of $1 \mathrm{mg}$ $\mathrm{ml}^{-1}$ of SOD preserved motility. However, Twigg et al. ${ }^{19}$ did not find any reduction in lipid peroxidation after the addition of between 100 and $500 \mathrm{IU} \mathrm{ml}^{-1}$ SOD.

\section{Other compounds}

Several other drugs have been tested, in combination or alone, for their effects on sperm parameters or lipid peroxidation.

In vitro studies led to the discovery of the positive effects of catalase in doses from 0.008 to $0.1 \mathrm{mg} \mathrm{ml}^{-1}$ or from 50 to $2000 \mathrm{IU} \mathrm{ml}^{-1}$ on motility, peroxidation and DNA damage. ${ }^{5,52,79}$ However, Twigg and colleagues ${ }^{19}$ found that the addition of 250,500 or $2000 \mathrm{IU} \mathrm{ml}^{-1}$ of catalase to sperm samples had no effect on lipid peroxidation. In the same study, no improvement was seen in lipid peroxidation after the addition of albumin at a dose of $0.3 \%-10 \%$.

Lewin and Lavon ${ }^{80}$ used coenzyme Q10 both in vivo and in vitro: the addition of $50 \mu \mathrm{mol} \mathrm{l}^{-1}$ in vitro resulted in a significant improvement in motility, whereas in vivo administration of $60 \mathrm{mg}$ day $^{-1}$ for 3.5 months (103 days) led to an increase in the fertilisation rate but had no effect on motility, morphology or concentration in 17 patients with low fertilisation rates after in vitro fertilisation with intracytoplasmic sperm injection for male factor infertility. An interesting in vivo study of 60 patients with idiopathic asthenozoospermia who received either placebo or $200 \mathrm{mg}$ day $^{-1}$ of coenzyme Q10 demonstrated significant improvement in motility after 6 months of treatment; this improvement was markedly reduced after a washout period of 3 months in treated subjects. $^{81}$

Comhaire and colleagues ${ }^{82}$ reported a study where 30 subfertile men were administered $16 \mathrm{mg}$ day $^{-1}$ of astaxanthin, a carotenoid that is not converted to vitamin A in humans, for 3 months. No significant improvements in concentration, motility, morphology or volume were seen in the 11 treated men compared with the 19 control patients.

Wong et al. ${ }^{70}$ found that in vivo administration of folic acid, either alone or in combination with zinc sulphate $\left(5\right.$ and $66 \mathrm{mg} \mathrm{day}^{-1}$ respectively), led to improved sperm concentration and count in their previously discussed controlled trial. However, the results were significant only for the 103 infertile men recruited for the study, whereas the 107 fertile men included did not undergo any improvement in sperm parameters.

\section{DISCUSSION}

Although numerous trials on the effects of antioxidants have been published in the last two decades, only a few have produced valuable, noteworthy results. However, even among these, the results are often contradictory and refer to small groups of individuals whose characteristics are often different, ranging from men with varicocele to those with OAT.

As already mentioned, small amounts of ROS are required for capacitation and the acrosome reaction. Paradoxically, a significant reduction in their concentration through the use of antioxidants might therefore have a negative effect on fertility. Similarly, an improvement in semen parameters does not necessarily translate into an increase in fertility, as individuals with normal sperm concentration, motility, viability and morphology might still be subfertile.

For these reasons, the primary outcome of any study should be pregnancy rate. However, only a few of the studies in this review evaluated this outcome, and no definitive answers have yet emerged from these trials. Fifteen in vivo studies $31,36,41,47,50,51,62-67,69,76,82$ included pregnancy rate among the end points measured; in two of these studies, a higher pregnancy rate was achieved, but was not statistically significant. ${ }^{47,76}$ In another two studies, the pregnancy rate was lower in the antioxidant-treated group than in the control group, although the comparison was against clomiphene citrate or mesterolone rather than placebo. ${ }^{50,51}$ In yet another two studies, no effect was observed on pregnancy rate, and in all of the remaining trials, a statistically significant increase in pregnancy rate was observed. ${ }^{31,67}$ In four of the studies showing increased pregnancy rates, there was an improvement in at least one sperm parameter and improved motility was observed in all parameters. ${ }^{36,65,66,69}$ An improved fertility rate was observed after the addition of antioxidants, most notably vitamins $\mathrm{A}$ and $\mathrm{E}$ and carnitine; in men with low selenium status, the addition of selenium increased the pregnancy rate in their partners.

The clinical heterogeneity of the results, the different drugs used and the doses administered, together with the small numbers of subjects recruited, all contribute to the lack of concrete evidence. The improvement in sperm parameters resulting from antioxidant therapy may result in a higher pregnancy rate, but this is not consistent and the possibility of negative effects on sperm DNA, capacitation and the acrosome reaction should be carefully evaluated. Furthermore, not all individuals are equally eligible for antioxidant therapy, and not all are likely to benefit in the same way from the same treatment. Further studies on this topic should address specific groups of subjects, preferably on a large scale, with strict inclusion and exclusion criteria, following the same treatment or treatments and with adequate follow-up. Firm recommendations for antioxidant therapy should be formulated after evaluating the effects of standardized doses in large randomized controlled trials, to establish if a given therapy is more likely to increase pregnancy rates in the partners of specific groups of infertile men. 


\section{COMPETING FINANCIAL INTERESTS}

The authors declare no financial or commercial conflicts of interest.

1 Sharlip ID, Jarow JP, Belker AM, Lipshultz LI, Sigman M et al. Best practice policies for male infertility. Fertil Steril 2002; 77: 873-82.

2 Hirsch A. ABC of subfertility: male subfertility. BMJ 2003; 327: 669-72.

3 Cooper TG, Noonan E, von Eckardstein S, Auger J, Baker HW et al. World Health Organization reference values for human semen characteristics. Hum Reprod Update 2010; 16: 231-45.

4 Griveau JF, Le Lannou D. Reactive oxygen species and human spermatozoa: physiology and pathology. Int J Androl 1997; 20: 61-9.

5 Lopes S, Jurisicova A, Sun JG, Casper RF. Reactive oxygen species: potential cause for DNA fragmentation in human spermatozoa. Hum Reprod 1998; 13: 896-900.

6 Aitken RJ, De Iuliis GN, Finnie JM, Hedges A, McLachlan RI. Analysis of the relationships between oxidative stress, DNA damage and sperm vitality in a patient population: development of diagnostic criteria. Hum Reprod 2010; 10: 2415-26.

$7 \mathrm{Kao}$ SH, Chao HT, Chen HW, Hwang TI, Liao TL et al. Increase in oxidative stress in human sperm with lower motility. Fertil Steril 2008; 89: 1183-90.

8 Aitken RJ, Clarkson JS, Fishel S. Generation of reactive oxygen species, lipid peroxidation, and human sperm function. Biol Reprod 1989; 41: 183-97.

9 Agarwal A, Saleh RA, Bedaiwy MA. Role of reactive oxygen species in the pathophysiology of human reproduction. Fertil Steril 2003; 79: 829-43.

10 Lewis SE, Sterling ES, Young IS, Thompson W. Comparison of individual antioxidants of sperm and seminal plasma in fertile and infertile men. Fertil Steril 1997; 67: 142-7.

11 Tremellen K. Oxidative stress and male infertility-a clinical prospective. Hum Reprod Update 2008; 14: 243-58.

12 Hendin BN, Kolettis PN, Sharma RK, Thomas AJ Jr, Agarwal A. Varicocele is associated with elevated spermatozoal reactive oxygen species production and diminished seminal plasma antioxidant capacity. J Urol 1999; 161: 1831-4.

13 Saleh RA, Agarwal A, Nada EA, El-Tonsy MH, Sharma RK et al. Negative effects of increased sperm DNA damage in relation to seminal oxidative stress in men with idiopathic and male factor infertility. Fertil Steril 2003; 79 (Suppl 3): 1597-605.

14 Agarwal A, Sharma RK, Desai NR, Prabakaran S, Tavares A et al. Role of oxidative stress in pathogenesis of varicocele and infertility. Urology 2009; 73: 461-9.

15 Abd-Elmoaty MA, Saleh R, Sharma R, Agarwal A. Increased levels of oxidants and reduced antioxidants in semen of infertile men with varicocele. Fertil Steril 2010; 94: 1531-4.

16 Henkel R, Kierspel E, Stalf T, Mehnert C, Menkveld R et al. Effect of reactive oxygen species produced by spermatozoa and leukocytes on sperm function in nonleukocytospermic patients. Fertil Steril 2005; 83: 635-42.

17 Lenzi A, Gandini L, Picardo M. A rationale for glutathione therapy. Hum Reprod 1998; 13: 1419-22.

18 Tarin JJ, Brines J, Cano A. Antioxidants may protect against infertility. Hum Reprod 1998; 13: 1415-6.

19 Twigg J, Fulton N, Gomez E, Irvine DS, Aitken RJ. Analysis of the impact of intracellular reactive oxygen species generation on the structural and functional integrity of human spermatozoa: lipid peroxidation, DNA fragmentation and effectiveness of antioxidants. Hum Reprod 1998; 13: 1429-36.

20 Abd-Allah AR, Helal GK, AI-Yahya AA, Aleisa AM, Al-Rejaie SS et al. Pro-inflammatory and oxidative stress pathways which compromise sperm motility and survival may be altered by L-carnitine. Oxid Med Cell Longev 2009; 2: 73-8.

21 Chandra A, Surti N, Kesavan S, Agarwal A. Significance of oxidative stress in human reproduction. Arch Med Sci 2009; 5 (1A): S28-42.

22 Makker K, Agarwal A, Sharma R. Oxidative stress and male infertility. Indian J Med Res 2009; 129: 357-67.

23 Yumura Y, Iwasaki A, Saito K, Ogawa T, Hirokawa M. Effect of reactive oxygen species in semen on the pregnancy of infertile couples. Int J Urol 2009; 16: 202-7.

24 Zini A, San Gabriel M, Baazeem A. Antioxidants and sperm DNA damage: a clinical perspective. J Assist Reprod Genet 2009; 26: 427-32.

25 Al-Gubory KH, Fowler PA, Garrel C. The roles of cellular reactive oxygen species, oxidative stress and antioxidants in pregnancy outcomes. Int J Biochem Cell Biol 2010; 42: 1634-50.

26 Bellver J, Meseguer M, Muriel L, García-Herrero S, Barreto MA et al. Y chromosome microdeletions, sperm DNA fragmentation and sperm oxidative stress as causes of recurrent spontaneous abortion of unknown etiology. Hum Reprod 2010; 25: 1713-21.

27 Desai N, Shabanegh E Jr, Kim T, Agarwal A. Free radical theory of aging: implications in male infertility. Urology 2010; 75: 14-9.

28 Kessopoulou E, Powers HJ, Sharma KK, Pearson MJ, Russell JM et al. A double-blind randomized placebo cross-over controlled trial using the antioxidant vitamin $\mathrm{E}$ to treat reactive oxygen species associated male infertility. Fertil Steril 1995; 64: 825-31.

29 Moilanen J, Hovatta O. Excretion of al pha-tocopherol into human seminal plasma after oral administration. Andrologia 1995; 27: 133-6.

30 Geva E, Bartoov B, Zabludovsky N, Lessing JB, Lerner-Geva L et al. The effect of antioxidant treatment on human spermatozoa and fertilization rate in an in vitro fertilization program. Fertil Steril 1996; 66: 430-4.

31 Rolf C, Cooper TG, Yeung CH, Nieschlag E. Antioxidant treatment of patients with asthenozoospermia or moderate oligoasthenozoospermia with high-dose vitamin $\mathrm{C}$ and vitamin E: a randomized, placebo-controlled, double-blind study. Hum Reprod 1999; 14: 1028-33.
32 Aitken RJ, Clarkson JS. Significance of reactive oxygen species and antioxidants in defining the efficacy of sperm preparation techniques. J Androl 1988; 9: 367-76.

33 Askari HA, Check JH, Peymer N, Bollendorf A. Effect of natural antioxidants tocopherol and ascorbic acids in maintenance of sperm activity during freeze-thaw process. Arch Androl 1994; 33: 11-5.

34 Verma A, Kanwar KC. Human sperm motility and lipid peroxidation in different ascorbic acid concentration: an in vitro analysis. Andrologia 1998; 30: 325-9.

35 Vezina D, Mauffette F, Roberts KD, Bleau G. Selenium-vitamin E supplementation in infertile men. Effects on semen parameters and micronutrient levels and distribution. Biol Trace Elem Res 1996; 53: 65-83.

36 Suleiman SA, Ali ME, Zaki ZM, el-Malik EM, Nasr MA. Lipid peroxidation and human sperm motility: protective role of vitamin E. J Androl 1996; 17: 530-7.

37 Kodama H, Yamaguchi R, Fukuda J, Kasai H, Tanaka T. Increased oxidative deoxyribonucleic acid damage in the spermatozoa of infertile male patients. Fertil Steril 1997; 68: 519-24.

38 Hughes CM, Lewis SE, McKelvey-Martin VJ, Thompson W. The effects of antioxidant supplementation during Percoll preparation on human sperm DNA integrity. Hum Reprod 1998; 13: 1240-7.

39 Donnelly ET, McClure N, Lewis SE. Antioxidant supplementation in vitro does not improve human sperm motility. Fertil Steril 1999; 72: 484-95.

40 Donnelly ET, McClure N, Lewis SE. The effect of ascorbate and alpha-tocopherol supplementation in vitro on DNA integrity and production of reactive oxygen species. Mutagenesis 1999; 14: 505-12.

41 Comhaire FH, Christophe AB, Zalata AA, Dhooge WS, Mahmoud AM et al. The effects of combined conventional treatment, oral antioxidants and essential fatty acids on sperm biology in subfertile men. Prostaglandins Leukot Essent Fatty Acids 2000; 63 : 159-65.

42 Sierens J, Hartley JA, Campbell MJ, Leathem AJ, Woodside JV. In vitro isoflavone supplementation reduces hydrogen peroxide-induced DNA damage in sperm. Teratog Carcinog Mutagen 2002; 22: 227-34

43 Keskes-Ammar L, Feki-Chakroun N, Rebai T, Sahnoun Z, Ghozzi H et al. Sperm oxidative stress and the effect of an oral vitamin $E$ and selenium supplement on semen quality in infertile men. Arch Androl 2003; 49: 83-94.

44 Greco E, lacobelli M, Rienzi L, Ubaldi F, Ferrero S et al. Reduction of the incidence of sperm DNA fragmentation by oral antioxidant treatment. J Androl 2005; 26: 349-53.

45 Omu AE, Al-Azemi MK, Kehinde EO, Anim JT, Oriowo MA et al. Indications of the mechanisms involved in improved sperm parameters by zinc therapy. Med Princ Pract 2008; 17: 108-16

46 Patel SR, Sigman M. Antioxidant therapy in male infertility. Urol Clin N Am 2008; 35: 319-30.

47 Paradiso Galatioto G, Gravina GL, Angelozzi G, Sacchetti A, Innominato PF et al. May antioxidant therapy improve sperm parameters of men with persistent oligospermia after retrograde embolization for varicocele? World J Urol 2008; 26: 97-102.

48 Critser JK, Huse-Benda AR, Aaker DV, Arneson BW, Ball GD. Cryopreservation of human spermatozoa. III. The effect of cryoprotectants on motility. Fertil Steril 1988; 50: 314-20.

49 Mazzilli F, Rossi T, Sabatini L, Pulcinelli FM, Rapone S et al. Human sperm cryopreservation and reactive oxygen species (ROS) production. Acta Eur Fertil 1995; 26: 145-8.

50 Abel BJ, Carswell G, Elton R, Hargreave TB, Kyle K et al. Randomised trial of clomiphene citrate treatment and vitamin C for male infertility. Br J Urol 1982; 54: 780-4.

51 Hargreave TB, Kyle KF, Baxby K, Rogers AC, Scott R et al. Randomised trial of mesterolone versus vitamin $\mathrm{C}$ for male infertility. Scottish Infertility Group. $\mathrm{Br} J$ Urol 1984; 56: 740-4.

52 Griveau JF, Le Lannou D. Effects of antioxidants on human sperm preparation techniques. Int J Androl 1994; 17: 225-31.

53 Hong CY, Lee MF, Lai LJ, Wang CP. Effect of lipid peroxidation on beating frequency of human sperm tail. Andrologia 1994; 26: 61-5.

54 Baker HW, Brindle J, Irvine DS, Aitken RJ. Protective effect of antioxidants on the impairment of sperm motility by activated polymorphonuclear leukocytes. Fertil Steril 1996; 65: 411-9.

55 Parinaud J, Le Lannou D, Vieitez G, Griveau JF, Milhet P et al. Enhancement of motility by treating spermatozoa with an antioxidant solution (Sperm-Fit) following ejaculation. Hum Reprod 1997; 12: 2434-6.

56 Lenzi A, Culasso F, Gandini L, Lombardo F, Dondero F. Placebo-controlled, doubleblind, cross-over trial of glutathione therapy in male infertility. Hum Reprod 1993; 8: 1657-62.

57 Lenzi A, Picardo M, Gandini L, Lombardo F, Terminali 0 et al. Glutathione treatment of dyspermia: effect on the lipoperoxidation process. Hum Reprod 1994: 9: 2044-50.

58 Oeda T, Henkel R, Ohmori H, Schill WB. Scavenging effect of $N$-acetyl-L-cysteine against reactive oxygen species in human semen: a possible therapeutic modality for male factor infertility? Andrologia 1997; 29: 125-31.

59 Ciftci H, Verit A, Savas M, Yeni E, Erel O. Effects of $\mathrm{N}$-acetylcysteine on semen parameters and oxidative/antioxidant status. Urology 2009; 74: 73-6.

60 Safarinejad MR, Safarinejad S. Efficacy of selenium and/or $\mathrm{N}$-acetyl-cysteine for improving semen parameters in infertile men: a double-blind, placebo controlled, randomized study. J Urol 2009; 181: 741-51.

61 Costa M, Canale D, Filicori M, D'Iddio S, Lenzi A. L-carnitine in idiopathic asthenozoospermia: a multicenter study. Italian Study Group on Carnitine and Male Infertility. Andrologia 1994; 26: 155-9. 
62 Vicari E, Calogero AE. Effects of treatment with carnitines in infertile patients with prostato-vesiculo-epididymitis. Hum Reprod 2001; 16: 2338-42.

63 Vicari E, La Vignera S, Calogero AE. Antioxidant treatment with carnitines is effective in infertile patients with prostatovesiculoepididymitis and elevated seminal leukocyte concentration after treatment with nonsteroidal anti-inflammatory compounds. Fertil Steril 2002; 78: 1203-8.

64 Lenzi A, Lombardo F, Sgrò P, Salacone P, Caponecchia L et al. Use of carnitine therapy in selected cases of male factor infertility: a double-blind crossover trial. Fertil Steril 2003: 79: 292-300.

65 Lenzi A, Sgrò P, Salacone P, Paoli D, Gilio B et al. A placebo-controlled double-blind randomized trial of the use of combined $L$-carnitine and $L$-acetyl-carnitine treatment in men with asthenozoospermia. Fertil Steril 2004; 81: 1578-84.

66 Cavallini G, Ferraretti AP, Gianarolli L, Biagiotti G, Vitali G. Cinnoxicam and L carnitine/acetyl-L-carnitine treatment for idiopathic and varicocoele-associated oligoasthenozoospermia. J Androl 2004; 25: 761-70.

67 Balercia G, Regoli F, Armeni T, Koverech A, Mantero F et al. Placebo-controlled doubleblind randomized trial on the use of $L$-carnitine, $L$-acetylcarnitine, or combined $L$ carnitine and $L$-acetylcarnitine in men with idiopathic asthenozoospermia. Ferti Steril 2005; 84: 662-71.

68 Sigman M, Glass S, Campagnone J, Pryor JL. Carnitine for the treatment of idiopathic asthenospermia: a randomized, double-blind, placebo-controlled trial. Fertil Steril 2006; 85: 1409-14.

69 Omu AE, Dashti H, Al-Ohman S. Treatment of asthenozoospermia with zinc sulphate: andrological, immunological and obstetric outcome. Eur J Obstet Gynaecol Reprod Biol 1998; 79: 179-84.

70 Wong WY, Merkus HM, Thomas CM, Menkveld R, Zielhuis GA et al. Effects of folic acid and zinc sulfate on male factor subfertility: a double-blind, randomized, placebocontrolled trial. Fertil Steril 2002; 77: 491-8.

71 Gavella M, Lipovac V, Marotti T. Effect of pentoxifylline on superoxide anion production by human sperm. Int J Androl 1991; 14: 320-7.

72 Gavella M, Lipovac V. Pentoxifylline-mediated reduction of superoxide anion production by human spermatozoa. Andrologia 1992; 24: 37-9.
73 McKinney KA, Lewis SE, Thompson W. The effects of pentoxifylline on the generation of reactive oxygen species and lipid peroxidation in human spermatozoa. Andrologia 1996; 28: 15-20.

74 Okada H, Tatsumi N, Kanzaki M, Fujisawa M, Arakawa S et al. Formation of reactive oxygen species by spermatozoa from asthenospermic patients: response to treatment with pentoxifylline. J Urol 1997; 157: 2140-6.

75 Iwanier K, Zachara BA. Selenium supplementation enhances the element concentration in blood and seminal fluid but does not change the spermatozoal quality characteristics in subfertile men. J Androl 1995; 16 441-7.

76 Scott R, MacPherson A, Yates RW, Hussain B, Dixon J. The effect of oral selenium supplementation on human sperm motility. Br J Urol 1998; 82: 76-80.

77 Kobayashi T, Miyazaki T, Natori M, Nozawa S. Protective role of superoxide dismutase in human sperm motility: superoxide dismutase activity and lipid peroxide in human seminal plasma and spermatozoa. Hum Reprod 1991; 6 987-91.

78 Aitken RJ, Buckingham D, Harkiss D. Use of a xanthine oxidase free radical generating system to investigate the cytotoxic effects of reactive oxygen species on human spermatozoa. J Reprod Fertil 1993; 97: 441-50.

79 Kovalski NN, de Lamirande E, Gagnon C. Reactive oxygen species generated by human neutrophils inhibit sperm motility: protective effect of seminal plasma and scavengers. Fertil Steril 1992; 58: 809-16.

80 Lewin A, Lavon $\mathrm{H}$. The effect of coenzyme $\mathrm{Q} 10$ on sperm motility and function. Mol Aspects Med 1997; 18: S213-9.

81 Balercia G, Buldreghini E, Vignini A, Tiano L, Paggi F et al. Coenzyme Q10 treatment in infertile men with idiopathic asthenozoospermia: a placebo-controlled, double-blind randomized trial. Fertil Steril 2009; 91 : 1785 92.

82 Comhaire FH, El Garem Y, Mahmoud A, Eertmans F, Schoonjans F. Combined conventional/antioxidant "Astaxanthin" treatment for male infertility: a double blind, randomized trial. Asian J Androl 2005; 7: 257-62. 